HaYward, A. C. (1957). J. gen. Microbiol. 16, 9-15

\title{
Detection of Gas Production from Glucose by Hetero- fermentative Lactic Acid Bacteria
}

\author{
BY A. C. HAYWARD \\ Department of Bacteriology, University of Birmingham
}

\begin{abstract}
SUMMARY: Several modifications of the Durham tube method for detecting gas production have been tested with a variety of heterofermentative lactobacilli, some of which had been described in the literature as failing to produce gas from glucose by this method. Gas production in Durham tubes was detected consistently when the surface of a tomato juice broth medium containing $0.5 \%$ or $2.5 \%(\mathrm{w} / \mathrm{v})$ glucose was sealed with liquid paraffin or with washed agar, but less consistently when the surface of the medium was unsealed. A minority of the strains examined grew weakly in a peptone + yeast extract medium containing glucose and produced very little titratable acidity or detectable gas. These produced large quantities of gas in the same medium when maltose replaced glucose.
\end{abstract}

Several methods may be used to differentiate between heterofermentative and homofermentative lactic acid bacteria. Analysis of the acid end products produced during the fermentation of hexoses shows that the former, including the genus Leuconostoc and some species of Lactobacillus, produce characteristic proportions of lactic and acetic acids, whereas the homofermentative species produce mainly lactic acid (Pederson, 1952). However, these two types may, for the most part, be differentiated by the production of gas from the fermentation of carbohydrates, which is confined to the heterofermentative organisms. This method, although simple in application, depends upon the reliability of the methods used for the detection of such gas (Davis, 1955a).

Many quantitative and qualitative methods of detecting gas production by lactic acid bacteria have been described (Gibson \& Abd-el-Malek, 1945); qualitative tests have been carried out in liquid, solid or semi-solid media. The results of tests in liquid medium by the conventional Durham tube method, which is adequate for detecting gas production by Gram-negative bacteria, have led to erroneous conclusions. For example, Strålfors (1950) concluded that there were no gas-producing lactobacilli in the mouth, a conclusion at variance with the observations of Rogosa, Wiseman, Mitchell, Disraely \& Beauman (1953) and Davis (1955a). The surface of the fermentation medium used by Strålfors was not sealed. The semi-solid medium of Gibson \& Abd-elMalek (1945) was sealed with a plug of nutrient agar, the displacement of which indicated gas production. Rogosa et al. (1953) detected gas production by the appearance of cracks in a $2 \%(\mathrm{w} / \mathrm{v})$ agar medium containing glucose + lactose; this solid medium was sealed with $2 \%$ agar, the surface of which carried a thin layer of heavy mineral oil to prevent the escape of gas. Rosen, Ragheb, Hunt \& Hoppert (1956) used a method similar to that described by Rogosa et al. (1953), in order to detect gas production by oral lactobacilli from rat. Although growth was observed in the medium, gas was produced in very small 
quantities only in a few tubes. They thus concluded that most of the strains isolated were homofermentative, but their method clearly did not give unequivocal results.

Moore \& Rainbow (1955), Camien, Dunn \& Salle (1947) and Camien \& Dunn (1955) described heterofermentative species of the genus Lactobacillus which fermented glucose very weakly, producing small quantities of titratable acidity, but which grew vigorously on a medium containing a pentose as energy source. Similarly, Cunningham \& Smith (1940) isolated a group of lactobacilli from silage which gave low yields of fermentation products on glucose + yeast extract + tryptone broth. Although these organisms gave the low ratio of lactic to acetic acid characteristic of heterofermentative lactobacilli, the quantities of carbon dioxide produced were small, and in some cases comparable with the amounts yielded by homofermentative species. During the systematic study of numerous lactobacilli from diverse saprophytic and parasitic sources I have isolated several lactobacilli of this type which grew weakly or not at all upon a medium containing glucose as major source of energy. These observations led to the following re-investigation of the factors which affect the detection by the Durham tube method of gas production by lactic acid bacteria and to a search for a suitable fermentable substrate for gas production by those lactobacilli which ferment glucose weakly. Two experiments are described in the following paper: (i) gas production by known heterofermentative lactobacilli was compared in tomato juice (TJ) broth containing different concentrations of glucose with the surface of the medium sealed or unsealed, and also in TJ agar medium; (ii) gas production was compared in a medium containing various carbohydrates but no tomato juice.

\section{METHODS}

Strains L3, L4, L5 and L6, studied by Moore \& Rainbow (1955), were supplied by courtesy of Dr C. F. Rainbow, Department of Applied Biochemistry, University of Birmingham. The remaining cultures were fresh isolates or were obtained from the National Collection of Industrial Bacteria, Teddington, Middlesex; these are listed in Table 1.

Freshly isolated strains were identified according to a simplified form of the classification described by Davis (1955b). Those listed without specific names did not belong to any recognizable species.

Media. In the first experiment the tomato juice (TJ) medium of Davis, Bisset \& Hale (1955) was used. Separate portions of this medium contained $0.5 \%$ or $2.5 \%(\mathrm{w} / \mathrm{v})$ glucose; a third portion containing $2.5 \%$ glucose and $0.5 \mathrm{ml} . / \mathrm{l}$. of a $2.0 \%(\mathrm{w} / \mathrm{v})$ solution of bromcresol green was solidified with $1.2 \%$ $(\mathrm{w} / \mathrm{v})$ New Zealand agar. These media were dispensed in $\mathbf{3 . 0} \mathrm{ml}$. quantities in $\frac{1}{2} \times 5$ in. tubes. The tubes containing liquid media were supplied with Durham tubes, and were sterilized by autoclaving at $120^{\circ} / 15 \mathrm{~min}$. The liquid media were inoculated with one drop of culture from a Pasteur pipette giving about $40 \mathrm{drops} / \mathrm{ml}$. The molten and cooled agar medium was heavily inoculated with a Pasteur pipette and rotated to distribute the organisms evenly. The $2.5 \%$ 
glucose TJ liquid medium was inoculated with each strain in triplicate; one of the tubes was sealed with about $2.0 \mathrm{ml}$. of sterile liquid paraffin, one with a similar quantity of molten $10 \%(\mathrm{w} / \mathrm{v})$ washed Japanese agar, and the third tube was not sealed. The $0.5 \%$ glucose $\mathrm{TJ}$ liquid medium was inoculated in

Table 1. Classification and names of lactobacilli used

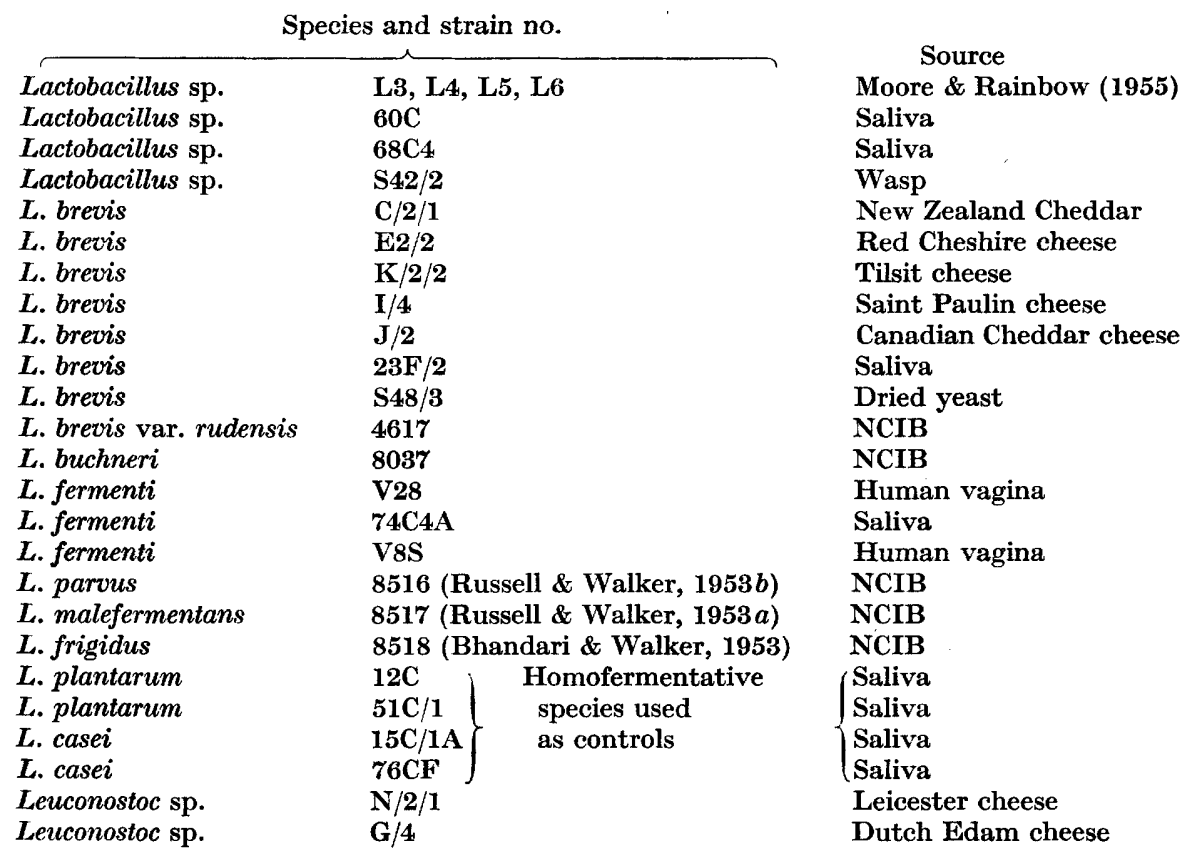

duplicate; one tube was sealed with liquid paraffin, the other was not sealed. The following strains were incubated at $28^{\circ}$ after inoculation with samples of 24 hr. TJ broth cultures: 8516, 8517, 8518, 8037, 4617, L3, L4, L5 and L6. All other strains were incubated at $37^{\circ}$ after inoculation with $14 \mathrm{hr}$. cultures.

In the second experiment the following basal medium was used: Peptone (Oxoid) $0.5 \%$ (w/v); yeast extract (Difco) $0.3 \%$ (w/v); salts A $0.5 \%$ (v/v); salts $\mathrm{B} 0.5 \%(\mathrm{v} / \mathrm{v})$; Tween $800.1 \%(\mathrm{v} / \mathrm{v})$; sodium acetate (hydrated) $0.5 \%$ $(\mathrm{w} / \mathrm{v})$. The constituents were diluted in glass-distilled water and the $\mathrm{pH}$ value of the medium adjusted to $6 \cdot 8-7 \cdot 0$. The salt solutions $A$ and $B$ were those used by Davis et al. (1955). Solution $A$ contained $10 \mathrm{~g}$. $\mathrm{KH}_{2} \mathrm{PO}_{4}$ and $10 \mathrm{~g} . \mathrm{K}_{2} \mathrm{HPO}_{4}$ in $100 \mathrm{ml}$. of distilled water; solution $\mathrm{B}$ contained $11.5 \mathrm{~g} . \mathrm{MgSO}_{4} \cdot 7 \mathrm{H}_{2} \mathrm{O}$, $2 \cdot 4 \mathrm{~g} . \mathrm{MnSO}_{4} \cdot 2 \mathrm{H}_{2} \mathrm{O}$ and $0 \cdot 68 \mathrm{~g}$. $\mathrm{FeSO}_{4} \cdot 7 \mathrm{H}_{2} \mathrm{O}$ in $100 \mathrm{ml}$. of distilled water. (Note: These formulae are given in full because Davis et al., in stating the composition of this medium, attributed both solutions to Rogosa et al. (1953), whereas the latter workers used only solution B).

Portions of the basal medium were supplemented with $2.5 \%(w / v)$ of glucose, lactose, sucrose, fructose or maltose. About 3.0 ml. quantities were added to 0.5 in. $\times 5$ in. tubes containing Durham tubes (c. 1.2 in. $\times 0.25$ in.). 
Sterilization was effected by autoclaving, momentarily, at $15 \mathrm{lb} . / \mathrm{sq}$. in. Tubes were inoculated with one drop of a $24 \mathrm{hr}$. TJ broth culture from a standard pipette. According to Moore \& Rainbow (1955) their strains grew well at $32-35^{\circ}$ in malt wort and so $\mathrm{L3}, \mathrm{L} 4, \mathrm{~L} 5$ and $\mathrm{L} 6$ were incubated at $34^{\circ}$, the remaining cultures at $36-37^{\circ}$. In sets of experiments tubes were incubated for 6 days without shaking, and examined daily for gas production.

\section{RESULTS}

The results of the two experiments are shown in Tables 2 and 3. In the unsealed tubes (Table 2 ), gas production was usually greatest after $2-3$ days of incubation, the volume decreasing later presumably because of loss of gas to the

\section{Table 2. Expt. 1: gas production detected by the Durham tube method in tomato juice $(T J)$ media}

Gas production in liquid medium was recorded as the degree to which the Durham tube was filled with gas, as follows : $0=$ Absence of gas in Durham tube; $1=$ bubble of gas at apex of Durham tube; $2=c$. one-third of Durham tube filled with gas; $3=c$. two-thirds of Durham tube filled with gas; $4=$ whole of Durham tube filled with gas. Gas production in agar was recorded as follows: $++=$ transverse cracks in agar, agar split apart and forced up the tube; $+=$ cracks in agar, but medium not forced apart; $-=$ medium entire. N.I. $=$ not inoculated. The numbers in brackets indicate the day of incubation at which maximum gas production was observed.

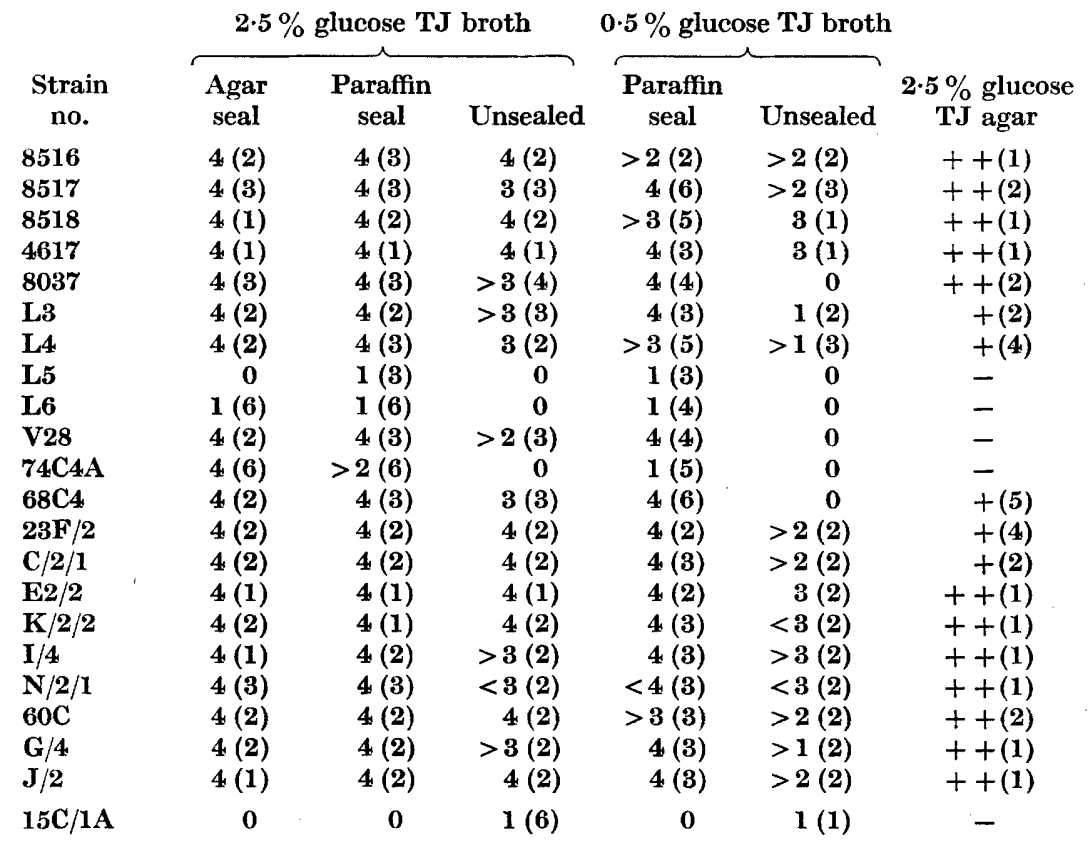

atmosphere. Durham tubes filled with gas were forced into the liquid paraffin seal or agar plug, the latter being forced up the tube by the pressure of gas not collecting in the Durham tube. 
In Expt. 1 (Table 2) homofermentative strains 12C, 51C/1 and 76CF, and in Expt. 2 strain $51 \mathrm{C} / 1$, did not produce detectable gas. As shown in Table 2. Lactobacillus casei (15 C/1 A) produced a very small quantity of gas in TJ broth, comparable with that produced by L5 and L6 in the same type of medium. In Expt. 2 (Table 3), however, L5 and L6 produced gas in large quantities in maltose medium. It has been observed in routine examinations that some strains of the homofermentative species $L$. casei and $L$. plantarum occasionally produce a bubble of gas at the apex of the Durham tube, but never in quantities comparable with those produced by heterofermentative species.

Table 3. Expt. 2: gas production by lactic acid bacteria from various carbohydrates in a peptone +yeast extract medium

The degree of gas production is recorded as in Table 2.

\begin{tabular}{|c|c|c|c|c|c|c|c|c|c|c|}
\hline \multirow[b]{2}{*}{$\begin{array}{c}\text { Strain } \\
\text { no. }\end{array}$} & \multicolumn{2}{|c|}{ Glucose } & \multicolumn{2}{|c|}{ Fructose } & \multicolumn{2}{|c|}{ Maltose } & \multicolumn{2}{|c|}{ Lactose } & \multicolumn{2}{|c|}{ Sucrose } \\
\hline & $\begin{array}{c}\text { Agar } \\
\text { seal }\end{array}$ & $\begin{array}{c}\text { Paraffin } \\
\text { seal }\end{array}$ & $\begin{array}{r}\text { Agar } \\
\text { seal }\end{array}$ & $\begin{array}{c}\text { Paraffin } \\
\text { seal }\end{array}$ & $\begin{array}{r}\text { Agar } \\
\text { seal }\end{array}$ & $\begin{array}{c}\text { Paraffin } \\
\text { seal }\end{array}$ & $\begin{array}{r}\text { Agar } \\
\text { seal }\end{array}$ & $\begin{array}{l}\text { ffin } \\
\text { seal }\end{array}$ & $\begin{array}{r}\text { Agar } \\
\text { seal }\end{array}$ & $\begin{array}{c}\text { Paraffin } \\
\text { seal }\end{array}$ \\
\hline L3 & $4(4)$ & $4(3)$ & $3(3)$ & $3(5)$ & $4(2)$ & $4(2)$ & 0 & 0 & $\mathbf{0}$ & $\mathbf{0}$ \\
\hline L4 & $>1(5)$ & $>1(6)$ & $3(3)$ & $<3(3)$ & $4(2)$ & $4(2)$ & 0 & 0 & $\mathbf{0}$ & 0 \\
\hline L5 & 0 & 0 & $3(5)$ & $>2(3)$ & $4(2)$ & $4(2)$ & 0 & $\mathbf{0}$ & $\mathbf{0}$ & $\mathbf{0}$ \\
\hline L6 & 0 & 0 & $>3(4)$ & $>2(3)$ & $4(2)$ & $4(2)$ & 0 & 0 & 0 & $\mathbf{0}$ \\
\hline V28 & $4(4)$ & $4(4)$ & $4(2)$ & $4(3)$ & $4(2)$ & $4(3)$ & 0 & o & $4(3)$ & $4(3)$ \\
\hline V8S & $4(2)$ & $4(2)$ & $<3(4)$ & $>2(2)$ & $4(1)$ & $4(1)$ & $4(1)$ & $4(1)$ & $4(1)$ & $4(r)$ \\
\hline $\mathrm{S} 42 / 2$ & $4(2)$ & $4(2)$ & 0 & 0 & $4(2)$ & $4(2)$ & 0 & 0 & 0 & 0 \\
\hline 68C4 & 0 & 0 & $<4(4)$ & $4(5)$ & $4(2)$ & $4(3)$ & 0 & $\mathbf{0}$ & $4(2)$ & $4(3)$ \\
\hline 4617 & $4(2)$ & $4(2)$ & $3(4)$ & $3(4)$ & $4(1)$ & $4(1)$ & 0 & 0 & $4(3)$ & $4(4)$ \\
\hline $\mathrm{S} 48 / 3$ & $4(3)$ & $4(3)$ & $>2(2)$ & $<3(3)$ & $4(2)$ & $4(2)$ & $\mathbf{0}$ & 0 & N.I. & N.I. \\
\hline 8518 & $4(2)$ & $4(2)$ & $4(3)$ & $4(2)$ & $4(2)$ & $4(2)$ & 0 & 0 & $4(2)$ & $4(2)$ \\
\hline 8037 & $4(5)$ & $4(4)$ & $4(2)$ & $4(2)$ & $4(3)$ & $4(4)$ & 0 & 0 & $4(3)$ & $4(3)$ \\
\hline
\end{tabular}

Strain $68 \mathrm{C} 4$, which in previous studies had failed to produce visible turbidity or titrable acidity in media containing glucose, also produced gas in a medium containing maltose, which according to Rogosa et al. (1953) is fermented by all heterofermentative lactobacilli. Lactobacillus fermenti (V8S) alone produced detectable gas in lactose medium. Gas production in fructose medium was generally less than in the other media.

Tables 2 and 3 show that very similar results were obtained in media sealed with agar or liquid paraffin; but in unsealed media gas accumulated in smaller quantities and was sometimes not detected. Results of tests in the agar medium used were frequently equivocal.

\section{DISCUSSION}

It is apparent that the Durham tube method may be used for the detection of gas production by lactobacilli provided that the surface of the medium be sealed, thus preventing the escape of gas, presumably mainly carbon dioxide. A minority of the tubes of unsealed media containing Durham tubes failed to accumulate gas. Evidence in the literature (for example, Strålfors, 1950) 
suggests that in other hands all such tubes were free of gas; a possible explanation of this difference is that wider test tubes than those used in my experiments have been generally employed in gas production tests, with the consequent exposure of a larger surface area of medium to the atmosphere.

The use of tomato juice in gas-production media may give misleading results, bearing in mind the observations of Chatfield \& Adams (1931), that tomatoes contain an average of $3 \cdot 4 \%$ total sugars : gas may be produced from carbohydrates present in the tomato juice, but probably not from glucose (compare the results for strain $68 \mathrm{C} 4$ ). It is noteworthy that the gas-production medium used by Gibson \& Abd-el-Malek (1945) included skimmed milk, tomato juice and $5.0 \%(\mathrm{w} / \mathrm{v})$ glucose, while that of Rogosa et al. (1953) included tomato juice, $\mathbf{0 . 2} \%(\mathrm{w} / \mathrm{v})$ lactose and $\mathbf{0 . 3} \%(\mathrm{w} / \mathrm{v})$ glucose. Although such media are adequate for the detection of gas production by most heterofermentative lactobacilli, it is concluded from this study that some strains require differentiation from non-gas-producing lactobacilli upon a medium containing maltose, in which all the heterofermentative lactobacilli examined were more readily defined as such than in any other medium.

\section{REFERENCES}

BhaNdARI, R. R. \& WALKER, T. K. (1953). Lactobacillus frigidus n.sp. isolated from brewery yeast. J. gen. Microbiol. 8, 330 .

Camien, M. N. \& Dunn, M. S. (1955). Pentose dependence of Lactobacillus gayonii and related species for early growth. Proc. Soc. exp. Biol., N.Y. 90, 183.

Camien, M. N., Dunn, M. S. \& Salle, A. J. (1947). The effect of carbohydrates on acid production by 24 lactic acid bacteria. J. biol. Chem. 168, 33.

Chatfield, C. \& Adams, G. (1931). Circ. U.S. Dep. Agric. no. 146. (Quoted by Camien et al. (1947). J. biol. Chem. 168, 33.)

Cunningham, A. \& Smith, A. M. (1940). The microbiology of silage made by the addition of mineral acids to crops rich in protein. II. The microflora. J. Dairy Res. 11, 243.

Davis, G. H. G. (1955a). The Classification of Lactobacillus Strains of Oral Origin. Ph.D. Thesis, University of Birmingham.

Davis, G. H. G. $(1955 b)$. The classification of lactobacilli from the human mouth. J. gen. Microbiol. 13, 481.

Davis, G. H. G., Bisset, K. A. \& Hale, C. M. F. (1955). Correlation between morphological and physiological characters in the classification of members of the genus Lactobacillus. J. gen. Microbiol. 13, 68.

Gibson, T. \& ABD-EL-Malek, Y. (1945). The formation of $\mathrm{CO}_{2}$ by lactic acid bacteria and Bacillus licheniformis and a cultural method of detecting the process. J. Dairy Res. 14, 35.

Moore, W. B. \& RaINBow, C. (1955). Nutritional requirements and biochemical activities of brewery lactobacilli. J. gen. Microbiol. 13, 190.

Pederson, C. S. (1952). In 'A symposium on the lactic acid bacteria'. Bact. Rev. 16, 227.

Rogosa, M., Wiseman, R. F., Mitchell, J. A., Disraely, M. N. \& Beauman, A. J. (1953). Species differentiation of oral lactobacilli from man including descriptions of Lactobacillus salivarius nov.spec. and Lactobacillus cellobiosus nov.spec. J. Bact. 65, 681.

Rosen, S., Ragheb, H. S., Hunt, H. R. \& Hoppert, C. A. (1956). A comparative study of oral lactobacilli isolated on two different media from the Hunt-Hoppert rats. J. dent. Res. 35, 291. 
Russell, C. \& WALker, T. K. (1953a). Lactobacillus malefermentans n.sp., isolated from beer. J. gen. Microbiol. 8, 160.

Russell, C. \& Walker, T. K. (1953b). Lactobacillus parvus n.sp., isolated from beer. J. gen. Microbiol. 8, 310.

Strålfors, A. (1950). Investigations into the bacterial chemistry of dental plaques. Odont. Tidskr. 58, 155.

(Received 15 June 1956) 